\title{
PENGARAHAN KESEHATAN IBU DAN JANIN DI MASA PANDEMI COVID-19 \\ Covid- 19
}

\author{
Nuril Lianatul Fitriah \\ IIK STRADA INDONESIA \\ nurillianatul@gmail.com
}

\section{- ABSTRAK}

Bencana non alam berupan pandemi virus corona (COVID-19) adalah masalah yang sedang dihadapi oleh banyak negara, termasuk Indonesia. COVID-19 juga berdampak terhadap pelayanan kesehatan ibu dan anak baik secara akses maupun kualitas. Himbauan Pemerintah tentang pembatasan kegiatan pada berbagai pelayanan umum, termasuk juga pelayanan kesehatan maternal dan neonatal dapat berdampak pada ibu hamil yang menjadi enggan datang ke fasilitas kesehatan untuk memeriksakan kehamilannya karena takut tertular COVID-19. Menanggapi hal tersebut perlu adanya pengetahuan dan pemahaman yang baik untuk masyarakat khususnya ibu hamil tentang COVID-19 dengan cara pemberian edukasi tentang COVID-19 pada ibu hamil. Tujuan kegiatan ini diharapkan dapat mengedukasi ibu hamil tentang kehamilan pada saat COVID-19.

\section{- Latar Belakang}

Kehamilan adalah suatu kondisi menyenangkan dimana tidak semua wanita yang telah menikah bisa hamil dan melahirkan, namun pada sebagian wanita ada juga menganggap bahwa kehamilan adalah masa yang tidak menyenangkan dan penuh dengan beban karena ketidakmampuan dalam penyesuaian diri terhadap berbagai perubahan yang terjadi pada masa kehamilan. Kehamilan juga dianggap sebagai peristiwa yang menimbulkan stress karena adanya tuntutan untuk beradaptasi dengan berbagai perubahan yang terjadi selama kehamilan (Kusuma, 2018).

Pada masa kehamilan ibu hamil diharapkan untuk menerima dan beradaptasi terhadap segala perubahan yang terjadi pada dirinya secara realita dan tanpa adanya 
tekanan dengan meningkatkan kesehatan fisik dan psikologis. (Widhiastuti \& Pratiwi, 2020).

Pada masa kehamilan juga perempuan akan selalu memperhatikan setiap detail perubahan yang terjadi pada dirinya. Hal ini berisiko menyebabkan ketakutan dan fantasi pada masa kehamilan serta merasa khawatir terhadap perubahan fisik dan psikologis (Yuswanto et al., 2017).

Kehamilan di masa pandemi COVID-19 sangat berisiko tinggi . Selain karena ibu hamil sangat rentan terinfeksi dengan virus SARS-CoV-2, pandemi juga telah mengakibatkan terganggunya sistem pelayanan kesehatan pada fasilitas kesehatan . Sehingga, hal tersebut berdampak terhadap terganggunya akses ibu hamil pada pelayanan kesehatan. Pemeriksaan kehamilan di fasilitas pelayanan kesehatan merupakan kebutuhan esensial yang harus didapatkan oleh ibu hamil .

Berdasarkan standar World Health Organization (WHO), ibu hamil perlu melakukan minimal empat kali pemeriksaan kehamilan di fasilitas kesehatan. Pada trimester pertama sebanyak satu kali, trimester kedua sebanyak satu kali dan trimester ketiga sebanyak 2 kali . Hal tersebut dilakukan agar kondisi kesehatan ibu hamil dan janin dapat dipantau secara periodik. Pemeriksaan kehamilan yang tidak dilakukan sesuai aturan akan menyebabkan risiko tinggi terhadap kondisi kesehatan pada ibu hamil. Risikorisiko tersebut, seperti keguguran, gangguan psikis, anemia, preeklampsia, eklampsia, bayi lahir prematur, bayi lahir dengan berat badan rendah dan kematian .

Penyebaran virus SARS-CoV-2 di Indonesia terus terjadi dan sangat pesat peningkatannya pada daerah-daerah yang menjadi episenter penyebaran virus tersebut, seperti Jakarta dan daerah sekitarnya atau Jabodetabek. Selama masa pandemi, wilayah metropolitan tersebut mengalami gangguan pelayanan kesehatan bagi ibu hamil. Bahkan pada awal pandemi, pelayanan kesehatan pada ibu hamil sempat dibatasi jam operasionalnya dan di beberapa lokasi sempat berhenti.

\section{- MASALAH}

Permasalahan mitra yang ditemukan adalah sebagai berikut:

1) Menurunnya kesadaran untuk melakukan periksa hamil ke fasilitas kesehatan.

2) Bagaimana gambaran masalah psikologis yang dihadapi ibu hamil pada masa pandemi Covid-19 di Indonesia?

3) Bagaimana pencegahan dan penanganan masalah psikologis yang dihadapi ibu hamil pada masa pandemi Covid-19 di Indonesia?

4) Bagaimana peran perawat dalam memberikan antenatal care pada masa pandemi Covid- 19 di Indonesia? 


\section{- TINJAUAN PUSTAKA}

Tinjauan pustaka sistematis ini diharapkan dapat menganalisis dampak pandemi COVID-19 terhadap akses pelayanan kesehatan pada ibu hamil serta dapat menambah wawasan mengenai gambaran psikologis yang dihadapi ibu hamil pada masa pandemi Covid-19.

\section{- PEMBAHASAN}

WHO menyebutkan perlu melakukan minimal empat kali pemeriksaan kehamilan di fasilitas kesehatan bagi ibu hamil. Pada trimester pertama sebanyak satu kali, trimester kedua sebanyak satu kali dan trimester ketiga sebanyak 2 kali . Hal tersebut dilakukan agar kondisi kesehatan ibu hamil dan janin dapat dipantau secara periodik.

Ibu hamil yang tidak melakukan pemeriksaan kehamilan secara periodik akan berdampak pada risiko kesehatan, seperti keguguran, gangguan psikis, anemia, preeklampsia, eklampsia, bayi lahir prematur, bayi lahir dengan berat badan rendah dan kematian . Sehingga, sangat perlu bagi ibu hamil untuk melakukan pemeriksaan kehamilan sesuai dengan standar WHO tersebut. Meski demikian, dalam kondisi pandemi COVID-19, disaat sistem pelayanan kesehatan terganggu dan aktivitas sosial masyarakat di batasi, maka akan memberikan dampak terhadap akses ibu hamil dalam melakukan pemeriksaan kehamilan. Gangguan tersebut berisiko tidak lengkapnya pemeriksaan kehamilan oleh ibu hamil.

Kurangnya pengetahuan ibu hamil tentang kelas hamil akan mempengaruhi status kesehatan dari ibu hamil. Pengetahuan yang baik akan menentukan ibu hamil dalam melakukan kunjungan kehamilan dan menjaga kehamilan tetap sehat. Pengetahuan yang kurang didasari oleh beberapa faktor salah satunya pendidikan yang kurang dan stigma tentang mitos yang ada dimasyarakat sehingga akan mempengaruhi rendahnya kunjungan ibu hamil. Semakin tinggi tingkat pendidikan ibu hamil tentang informasi kesehatan dapat merubah status kesehatan ibu hamil untuk memanfaatkan pelayanan kesehatan. (Patriajati \& Sriatmi, 2019) 
Terdapat beberapa faktor yang dapat mempengaruhi kurangnya pengetahuan ibu hamil tentang pentingnya kunjungan ANC dan kelas ibu hamil. Lingkungan yang kurang mendukung dapat menyebabkan kerentanan terhadap status kesehatan ibu hamil. Sistem kesehatan yang dominan di lingkungan ibu hamil berpengaruh terhadap perubahan perilaku untuk mengakses pelayanan kesehatan (Rachmawati et al., 2017).

Masa pandemi covid-19 menyebabkan kekhawatiran ibu hamil rentan tertular saat melakukan kunjungan ANC di pelayanan kesehatan. Faktor lain adalah status ekonomi yang berpengaruh besar terhadap perubahan perilaku ibu hamil dalam mengambil keputusan dalam memanfaatkan pelayanan kesehatan atau mengakses dan merubah perilaku kesehatan. Dasar pengetahuan yang dimiliki oleh seseorang dapat mempengaruhi lingkungan yang ada disekitarnya. Pengetahuan merupakan bagian yang sangat penting untuk menentukan tindakan seseorang. (Agustine et al., 2019)

Dengan diberikannya edukasi dapat memberikan pemahaman ibu hamil tentang pentingnya memperhatikan kesehatan selama kehamilan walaupun dalam kondisi pandemi. Menurut Potter \& Perry (2009) edukasi adalah suatu proses yang mendorong adanya pembelajaran, dimana pembelajaran itu adalah menambah pengetahuan baru, sikap serta ketrampilan melalui penguatan praktek dan pengalaman tertentu (Perry and Potter, 2009).

Diadakannya edukasi ibu hamil menjadi paham tentang pencegahan infeksi COVID19 bagi ibu hamil, prosedur pemeriksaan kehamilan di era pandemi, cara menjaga kesehatan ibu hamil di era pandemi, upaya yang dilakukan ketika ibu hamil sakit di era pandemi. Hal tersebut terlihat dengan adanya peningkatan pengetahuan ibu hamil sebelum dan setelah diberikan edukasi.

Diharapkan dengan peningkatan pengetahuan ibu hamil tetap bersedia memeriksakan kehamilannya secara teratur untuk memantau pertumbuhan dan perkembangan janin dengan tetap memperhatikan protokol kesehatan. Hal tersebut sejalan dengan tujuan edukasi yaitu mengembangkan perilaku positif dalam rangka meningkatkan kesehatan (Maulana, 2009).

\section{- KESIMPULAN}

1) Pandemi COVID-19 telah berdampak buruk terhadap pelayanan kebidanan di Indonesia. Masih banyak ibu hamil yang terpaksa tidak melakukan pemeriksaan kehamilan dan kesulitan untuk mengakses pelayanan kebidanan. Ibu hamil membutuhkan pelayanan kebidanan yang aman di masa pandemi COVID-19.

2) Adanya peningkatan pengetahuan ibu hamil tentang pencegahan infeksi COVID-19 bagi ibu hamil, prosedur pemeriksaan kehamilan di era pandemi, cara menjaga 
kesehatan ibu hamil di era pandemi, upaya yang dilakukan ketika ibu hamil sakit di era pandemi.

3) Pemahaman ibu hamil tentang pencegahan infeksi COVID-19 bagi ibu hamil, prosedur pemeriksaan kehamilan di era pandemi, cara menjaga kesehatan ibu hamil di era pandemi, upaya yang dilakukan ketika ibu hamil sakit di era pandemi, yang kemudian menyadari untuk tetap memeriksakan kehamilannya selama pandemi COVID-19 dengan menerapkan protokol kesehatan agar pertumbuhan dan perkembangan janin dapat terpantau dengan baik.

\section{- DAFTAR PUSTAKA}

Kemenkes RI (2020) Pedoman Bagi Ibu Hamil, Bersalin, Nifas dan Bayi Baru Lahir Di Era Pandemik COVID-19. Jakarta: Dirjen Kesga dan Kesmas.

Maulana (2009) Promosi Kesehatan. Jakarta: EGC.

Agustine, U., Christina, M., \& Sukartiningsih, E. (2019). Keterkaitan Sosial Budaya Dengan Pelaksanaan Antenatal Care (ANC) Di Wilayah Kerja Puskesmas Kambaniru. Jurnal Kesehatan Primer, 4(1), 42-54. https://doi.org/https://doi.org/10.31965/jkp

Badan Kependudukan dan Keluarga Berencana Nasional. (2018). Survey Demografi dan Kesehatan Indonesia 2017. In bps.go.id. https://doi.org/0910383107 [pii] \r10.1073/pnas.0910383107

Badan Pusat Statistik. (2019). Profil Statistik Kesehatan 2019. In Badan Pusat Statistik (Ed.), Profil statistik kesehatan. Badan Pusat Statistik. https://www.bps.go.id https://e-jurnal.stikesalirsyadclp.ac.id/index.php/jpma/article/view/259 